\title{
THE EFFECT OF REWARD STRATEGIES ON THE SUCCESS OF CROWDFUNDING CAMPAIGNS
}

\author{
JORGE R. VERSCHOORE ${ }^{1}$ \\ http://orcid.org/0000-0001-7588-7871 \\ MARIANA D. M. ARAÚJO \\ (iD) https://orcid.org/0000-0002-6186-4414
}

To cite this paper: Verschoore, J. R., \& Araújo, M. D. M. (2020). The effect of reward strategies on the success of crowdfunding campaigns. Revista de Administração Mackenzie, 21 (4), 1-25. doi:10.15 90/1678-6971/eRAMR200139

Submission: July 23, 2019. Acceptance: Feb. 21, 2020.

Vale do Rio dos Sinos University (Unisinos), Porto Alegre, RS, Brazil.

\section{(c) $\mathbf{B Y}$




\section{ABSTRACT}

Purpose: The purpose of this paper is to analyze the effect of reward strategies on the success of crowdfunding campaigns.

Originality/value: The study contributed to the knowledge of crowdfunding reward strategies. Through a comparative analysis approach, the study demonstrated differences in the effect of tangible, symbolic and collective rewards on the success of crowdfunding campaigns.

Design/methodology/approach: The study employs the approach of Qualitative Comparative Analysis (QCA) to analyze the CF campaigns of catarse.me, a Brazilian crowdfunding platform.

Findings: Tangible rewards, such as something special and purchase me, have a positive effect on the success of crowdfunding campaigns. Symbolic and collective rewards, such as collectible tokens, pursuit of pleasure, and top it up, cannot replace the material incentives of tangible rewards. The main findings show the opportunities for combinations of reward strategies on collective fundraising. Based on the study, entrepreneurs are able to plan a reward strategy for crowdfunding campaigns. Results are applicable to reward-based crowdfunding and cannot be generalized to other platforms around the world.

\section{KEYWORDS}

Crowdfunding. Entrepreneurship. New ventures. Success factors. Rewards. 


\section{INTRODUCTION}

Collective funding, known as crowdfunding (CF), has been praised as a viable option to raise money for new ventures (Lehner, 2013). From hardware manufacturing purposes to coping with social problems, the entrepreneurs have used the wealth of crowds to make their projects happen (Gerber \& Hui, 2013; Frydrych, Bock, Kinder, \& Koeck, 2014). Some studies on the phenomenon have focused on the explanation of the success of CF campaigns (Kraus, Richter, Brem, Cheng, \& Chang, 2016), taking into account the entrepreneur's profile, such as practice, previous experience and involvement in the CF community (Hobbs, Grigore, \& Molesworth, 2016; Burtch, Ghose, \& Wattal, 2015). Other studies considered the entrepreneur's relationship with his social network and the beneficial interactions among agents (Verschoore \& Zuquetto, 2016; Turi, Domingo-Ferrer, Sánchez, \& Osmani, 2017), as well as the intensity of the campaign's publicity and the campaign updates (Kuppuswamy \& Bayus, 2018). However, the explanatory factors of CF campaigns success continue to motivate debates and research (McKenny, Allison, Ketchen Jr., Short, \& Ireland, 2017; Kaartemo, 2017; Crosetto \& Regner, 2018).

Rewards are a fundamental part of a CF campaign, given that the amounts contributed in support receive a product or service in return (Frydrych et al., 2014). The motivation to support and how much support is given to a campaign are therefore influenced by this retribution. Rewards can also help to solve the threshold problem of collective action, in which an individual decision to support a project depends on how many others have made the same choice (Granovetter, 1978; Easley \& Kleinberg, 2010). Over the last decades, scholars have shown the positive and negative effect of rewards on collective action (Frey \& Jegen, 2001; Bénabou \& Tirole, 2006). This debate has brought to light the relevance of reward strategies for the collective action initiatives.

In this context, Thürridl and Kamleitner (2016) studied the CF phenomena in light of the rewards offered to the potential backers. They proposed seven reward strategies that would explain the success or failure of a CF campaign. Among the proposed strategies are purchase me, top it up, collectible tokens, and two complementary strategies, highly appreciated and let's collaborate (Thürridl \& Kamleitner, 2016). Despite recent efforts to understand the success factors of CF campaigns, the outcomes of reward strategies remain unclear. There is a research gap in understanding the positive and negative effects of reward strategies on collective action. 
Starting with the reward strategies proposed by Thürridl and Kamleitner (2016), this study addresses the effects of reward strategies on the success of CF campaigns. To deepen the knowledge of the phenomenon, we investigate comparatively the effect of each of the seven reward strategies on CF campaigns.

The contribution of the study is threefold. First, the study adds to a literature that has yielded mixed results with respect to the effect of rewards on collective action. Second, the study demonstrates the relationship between the main reward strategies and the success of CF campaigns. Third, the study guides entrepreneurs to plan reward strategies for crowdfunding campaigns. Qualitative Comparative Analysis (QCA) method was used since it enables the establishment of causal relations of the variations of social phenomena in an eminently qualitative approach (Ragin, 1987). The catarse.me, a Brazilian platform, was chosen as the empirical field, for its trajectory and robustness. The data corpus for the analysis covered 2,614 rewards, of which 1,468 were related to successful campaigns and 1,146 to unsuccessful campaigns.

Besides this introduction, the article is structured in five more sections. In the next section, we discuss crowds, collective action and the CF phenomenon, as well as reward strategies. In the following section, we present the QCA method and the choices and methodology procedures we have made. In the fourth section, we presented the results of the qualitative comparative analysis and, in the following section, we discuss them in light of our theoretical assumptions. The last section presents our final comments and our suggestions for the development of the CF research.

\section{CROWDS, COLLECTIVE ACTION AND CROWDFUNDING}

A crowd is a large group of people who have gathered together. According to Momboisse (1967), crowds comprise individuals not organized or unified, who are in the same place or are involved in some form of expressive or aggressive behavior. This research is focused on a specific type of crowd: the conventional crowd. The conventional crowd is a set of people which are gathered for a specific purpose with crowd members who share common interests (Momboisse, 1967). A conventional crowd needs a goal. Direction is vital for the crowd to continue existing. The goal is known and is near. Proclaiming the goal and the spreading of how to accomplish it are enough to make this type of crowd form. A conventional crowd forms with reference to a quickly attainable goal (Canetti, 1984). 
Recently, information technology leveraged the power of crowds through distributed systems that combine the strengths of humans and computers to address wicked problems and to accomplish complex tasks (Michelucci \& Dickinson, 2016). Everyone can collaborate with ideas anytime from anywhere. This web-based distributed problem-solving and production model that harnesses creative solutions of a large group of people is called crowdsourcing (Brabham, 2008). The rise of crowdsourcing soon stimulated the emergence of crowdfunding (CF). CF is defined as a community-enabled form of project financing. It is an open invitation, mainly through the internet, for raising financial resources, either in the form of donation, or in exchange for a future product or some form of reward (Belleflame, Lambert, \& Schwienbacher, 2014; Mollick, 2014). There are four different contexts of the CF application: donation-, loan-, equity-, and reward-based CF. In the present study, the campaigns were analyzed in the context of rewards, which are characterized as a monetary exchange provided by the backers, for some kind of benefit on the part of the entrepreneur (Burtch et al., 2015).

Since CF based on rewards is not driven by charity, there are objectives, motivations, and expectations of the reciprocity that are considered by the entrepreneurs and the backers (Boeuf, Darveau, \& Legoux, 2014). Fundraising is the main motivation for the entrepreneurs and, yet, it is not the only one. Other motivations are equally important, such as the reduction of marketing costs, mobilization and connection with people, as well as the feedback that can improve or modify the original project and market and validation tests (Boeuf et al., 2014; Valančienè \& Jegelevičiūtè, 2014). Backers are not regular investors. Participation in a CF campaign is a social activity that results in benefits to the community. Thus, backers feel they are part of a special or privileged group of backers or consumers who are making a project financially viable (Belleflamme \& Lambert, 2014; Belleflamme et al., 2014). Hence, the entrepreneurs invariably seek to generate value and experience to attract both the CF community investment and the resources from conventional backers, such as venture capitalists (Gleasure, 2015).

The interaction between the entrepreneurs and the backers is carried out through a platform (Valančienè \& Jegelevičiūtè, 2014). CF platforms play the role of social intermediaries (Colombo, Franzoni, \& Rossi-Lamastra, 2015). The entrepreneur can create pages concerning his/her campaigns, announce ideas, keep the project in control, communicate with the backers and receive payments through the platform infrastructure (Belleflamme \& Lambert, 2014). Scholars postulate that the intrinsic characteristics of the entrepreneur, evidenced by their contributions in the CF community, is a 
positive factor for the success of the campaign (Koch \& Siering, 2015; Kraus et al., 2016). Entrepreneurs with successful campaigns have significantly more backers than entrepreneurs with unsuccessful ones (Kuppuswamy \& Bayus, 2018).

Another theoretical postulation is that active entrepreneurs on the platform have a greater chance of success (Boeuf et al., 2014; Colombo et al., 2015; Koch and Siering, 2015; Zheng, Li, Wu, \& Xu, 2014). It was evidenced that previous involvement with the community entails benefits for fundraising, although the time spent to create this relationship has not been considered (Hobbs et al., 2016). As a result, it is proposed that the platforms allow for data transparency according to the entrepreneur's choice (Burtch et al., 2015). In addition, comprehensive information about the product or service the entrepreneur wishes to fund increases the chance of the campaign's success (Kuppuswamy \& Bayus, 2018). Backers' decisions are based on the project information and mainly on information from other backers, reinforcing the assumption that a CF campaign is, to an extent, socially built (Schijven \& Hitt, 2012).

In this way, the funding goal of a campaign has an influence on the decisions of other possible backers, generating a network effect, that is: the closer the campaign is to the goal, the more backers end up making financial contributions (Agrawal, Catalini, \& Goldfarb, 2015; Belleflamme \& Lambert, 2014). In addition, as the campaign gains more backers, the greater the quality signals it conveys to new backers. Studies point out that backers are more likely to contribute toward the end of the campaign when the purpose of the funding is almost attained and the chance of getting their reward is greater. When a campaign exceeds $50 \%$ of the collection goal, it has a $95 \%$ chance of reaching its goal (Agrawal et al., 2011, 2015). According to Easley and Kleinberg (2010, p. 514), "This is an example of a collective action problem, where an activity produces benefits only if enough people participate". The collective action problem is that individual decision depends in part on how many others make which choice (Balestrin \& Verschoore, 2014).

Different backers require different levels of cost and benefits to support a project. The concept for describing such variation among individuals is that of the threshold. A backer's threshold for supporting a CF campaign is outlined by the proportion of the group he/she would have to join before he would do so (Granovetter, 1978). In other words, before they decide to engage, prospective backers assess the potential impact of their own contribution (Passy \& Giugni, 2001). Because of this collective action problem, Kraus et al. (2016) suggest initiating campaign communication by family, 
friends and colleagues, arguing that they are crucial to the first stage of CF dissemination, even if these people end up supporting the campaign only once (Kuppuswamy \& Bayus, 2018). In a deeper analysis, Verschoore and Zuquetto (2016) have identified that the entrepreneur starts his/her campaign through the smallest polarization of his network to activate the first backers while opting to use weaker ties as channels of information distribution for the campaign. The expansion of the support network beyond family and friends is the key to the success of the campaign (Davidson \& Poor, 2015).

To do so, the CF campaigns, in general, offer rewards. In reward-based campaigns, material and social rewards are used strategically to attract more backers to the campaign. However, studies identified that, under particular conditions, monetary rewards have a perverse effect, undermining motivation and reducing the total contribution provided by agents (Frey \& Jegen, 2001). Rewards are weak behavior reinforcers in the short-run (Bénabou \& Tirole, 2003) and have a detrimental effect on collective action. On the other hand, there is also evidence to support the basic premise of economics that rewards are generally effective (Bénabou \& Tirole, 2006). It depends on the alignment of the reward with the volunteers' expectations. Usually, CF campaigns offer a wide range of reward strategies. Campaigns that aim to finance social causes commonly offer symbolic rewards. CF campaigns for product development choose to offer merchandise items, recognition or community benefits (Gerber, Hui, \& Kuo, 2012). Some campaigns offer a mixed reward strategy. The discussion of CF reward strategies will be further elaborated in the next section.

\section{REWARD STRATEGIES}

Rewards are among the main motivations for the backer's contribution (Hobbs et al., 2016). However, rewards alone do not show a positive influence on campaign success, which means that it is not the mere existence of any retribution that motivates campaign backers (Hörisch, 2015). For this, it is important to analyze what rewards will be offered and the best way to combine them to attract more investment to the campaign, making potential buyers become backers (Gerber et al., 2012; Thürridl \& Kamleitner, 2016). It is possible to offer different possibilities in a campaign since these offer different combinations of rewards. On average, seven distinct categories are offered to backers, who raise approximately US $\$ 70$ per backer (Kuppuswamy 
\& Bayus, 2018). Chen, Thomas, and Kohli, (2016) conducted a subgroup analysis on the kickstarter.com platform and demonstrated that campaigns with six reward levels had the highest average campaign collection ratios (Chen et al., 2016).

In this context, Thürridl and Kamleitner (2016) analyzed the CF campaigns using eight dimensions as a superscript that reflects the key reward identity and defined seven generic reward strategies adopted in the campaigns. They rated five main strategies and two complementary strategies. The strategies were classified into purchase me when a person buys the product in advance for a value below the one that will be released in the market. Top it up refers to a reward type that is presented in single packages and, as its value is changed, the backer keeps the packages of the previous rewards and new ones are added. Collectible tokens are symbolic physical rewards or gifts of low value in exchange for funding (Thurridl \& Kamleitner, 2016).

When the campaign uses limited edition rewards, which remain available only during the campaign, the reward strategy used is called something special. The pursuit of pleasure reward is used when the focus is on offering intangible benefits, such as meetings and dating events. There is also the reward called highly appreciated, which may occur publicly or privately, and the reward of let's collaborate, in which the entrepreneur is free to allow backers to contribute to the public participation (Burtch et al., 2015; Thürridl \& Kamleitner, 2016). The five main strategies and two complementary strategies are presented in Figure 3.1, with their description and an example of application collected alongside the catarse.me platform.

\section{(Figure 3.1)}

\section{REWARD STRATEGIES CLASSIFICATION}

\begin{tabular}{|c|c|c|c|}
\hline & Reward & Description & Example \\
\hline \multirow{2}{*}{ 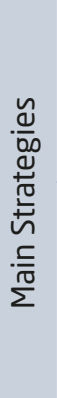 } & Purchase me & $\begin{array}{l}\text { Buy the product in advance for a } \\
\text { value below the one that will be } \\
\text { released in the market. }\end{array}$ & $\begin{array}{l}\text { "Backers will receive an original photo of the } \\
\text { exhibition printed on professional photo } \\
\text { paper in an individual, black-coated acrylic- } \\
\text { protected frame" (Catarse, 2017). }\end{array}$ \\
\hline & Top it up & $\begin{array}{l}\text { Rewards appear in unique } \\
\text { packages, and as their value is } \\
\text { changed, the reward package } \\
\text { is retained and only new ones } \\
\text { are added. }\end{array}$ & $\begin{array}{l}\text { "Backers will receive all the previous } \\
\text { rewards: the thank-you letter, the 'Honorary } \\
\text { Superator' diploma and the official } \\
\text { 'Superator' shirt" (Catarse, 2017). }\end{array}$ \\
\hline
\end{tabular}




\section{(Figure 3.1 (conclusion))}

REWARD STRATEGIES CLASSIFICATION

\begin{tabular}{|c|c|c|c|}
\hline & Reward & Description & Example \\
\hline \multirow{3}{*}{ 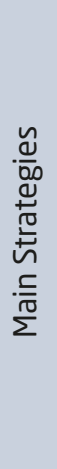 } & $\begin{array}{l}\text { Collectible } \\
\text { tokens }\end{array}$ & $\begin{array}{l}\text { Symbolic physical rewards or } \\
\text { low-value gifts in exchange for } \\
\text { funding. }\end{array}$ & $\begin{array}{l}\text { "A souvenir and a t-shirt of the cities where } \\
\text { I'll go on my photographic expeditions" } \\
\text { (Catarse, 2017). }\end{array}$ \\
\hline & $\begin{array}{l}\text { Something } \\
\text { special }\end{array}$ & $\begin{array}{l}\text { Limited edition rewards, which } \\
\text { remain available only during the } \\
\text { campaign. }\end{array}$ & $\begin{array}{l}\text { "1 Cryptocerveja - Handmade beer, made } \\
\text { for the cryptorave } 2016.600 \text { ml Bottle. } \\
\text { Withdrawal on day: there will be no mailing. } \\
\text { There will be no sale on the day" } \\
\text { (Catarse, 2017). }\end{array}$ \\
\hline & $\begin{array}{l}\text { Pursuit of } \\
\text { pleasure }\end{array}$ & $\begin{array}{l}\text { Intangible rewards, such as } \\
\text { meetings and meeting events. }\end{array}$ & $\begin{array}{l}\text { "Right to a photoshoot each, with my new } \\
\text { equipment" (Catarse, 2017). }\end{array}$ \\
\hline \multirow{2}{*}{ 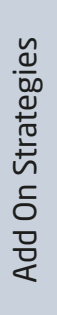 } & $\begin{array}{l}\text { Highly } \\
\text { appreciated }\end{array}$ & $\begin{array}{l}\text { Recognition which can be public } \\
\text { or private. }\end{array}$ & $\begin{array}{l}\text { "We'll send you a thank-you letter } \\
\text { signed by the creators of Super Cooler" } \\
\text { (Catarse, 2017). }\end{array}$ \\
\hline & $\begin{array}{l}\text { Let's } \\
\text { collaborate }\end{array}$ & $\begin{array}{l}\text { The entrepreneur has the } \\
\text { freedom to allow the crowd to } \\
\text { contribute to public participation } \\
\text { in the campaign or as volunteers. }\end{array}$ & $\begin{array}{l}\text { "You send two suggestions of names, one } \\
\text { for model } 01 \text { and one for model } 02 \text {. } \\
\text { For each group of ten backers, we'll select } \\
\text { the most creative one" (Catarse, 2017). }\end{array}$ \\
\hline
\end{tabular}

Source: Elaborated by the authors based on Thürrild and Kamleitner (2016).

Other studies point to the rewards when analyzing backers' motivations for the campaign. Some may be motivated to gain preferential access to the product or some symbolic personalized reward for their participation in the campaign (Kuppuswamy \& Bayus, 2018). These backers are attracted by the value of becoming the first to obtain the product (Gerber et al., 2012) since utilitarian products positively influence investment levels compared to the hedonic products (Chen et al., 2016).

On the other hand, some backers value the experience of consumption, not only the investment to be made (Belleflamme et al., 2014). One opportunity to build involvement is to seek suggestions from the backers about the product's improvements. Thus, the entrepreneurs listen to their target audience and can even obtain negative feedback, accessing information and allowing them to validate their product (Bernoff \& Li, 2008; Belleflamme and Lambert, 2014; Stieger, Matzler, Chatteriee, \& Ladstaetter-Fussenegger, 2012). However, there is no consensus regarding reward strategies. The literature throws different perspectives on the phenomenon and it is not known 
which rewards impact the success of a campaign (Gerber et al., 2012; Hörisch, 2015).

\section{METHODOLOGY}

The paper adopts comparative empirical research using the QCA method with the use of the fuzzy set (Ragin, 1987, 2000). The QCA method was developed by Ragin (1987) based on the binary logic of boolean algebra. It relies on the fs software/QCA to conduct comparative research and interpret data qualitatively and, at the same time, establish causal relations of the variations of social phenomena (Dias, 2014; Rihoux, 2003; Ragin, 1987). Since Ragin published The comparative method in 1987, QCA applications have spread across various disciplines and have expanded from small-N applications to large-N studies (Thomann \& Maggetti, 2017).

We investigated CF campaigns posted on catarse.me, a Brazillian platform. Catarse.me was the first to operate "all or nothing" campaigns, in which the entrepreneur sets a fundraising goal and keeps nothing unless this goal is achieved. The platform is solid. It reached a total of 4,500 campaigns funded, moving around 390 thousand backers and reaching a total of US\$ 20 million collected up to the year 2017 (Catarse, 2017). The selected thematic categories for the research were architecture and urbanism (AUB), photography (PHO), fashion and design (FAD) and science and technology (SCT). We chose these categories in order to get closer to the campaigns launched in the platforms of worldwide relevance, such as kickstater.com and indiegogo.com, which are recognized by having new technology and innovation campaigns.

In this research, we chose to compare the reward strategies of successful campaigns and unsuccessful campaigns. Successful campaigns have reached or exceeded the stipulated goal. Unsuccessful campaigns could not reach their fundraising goals. The campaigns were posted on the catarse.me platform during the period from March 2011 to November 2017. We identified 338 campaigns, of which 175 were successful campaigns and 163 were unsuccessful campaigns in these four categories. We analyzed and classified the rewards of the 338 campaigns, according to the strategies that were contained in the description of the campaign on the catarse.me platform, based on the seven categories of study by Thürridl and Kamleitner (2016) summarized in Figure 3.1. In all, we reached the number of 2,614 rewards in the 338 selected campaigns, of which 1,468 rewards were for successful campaigns and 1,146 rewards were for unsuccessful campaigns. 
Following the assumptions of the QCA method, we adopted the data analysis procedure using the fuzzy method of coding strategies (Dias, 2015; Ragin, 1987). To encode them, we chose to use the initial letters of the strategies in their identification: the purchase me strategy received the purch code; top it up was coded as topit; collectible tokens were coded as colle; something special as somet; pursuit of pleasure as pursu; highly appreciated as high; and finally let's collaborate was coded as lets. Figure 4.1 synthesizes the coding used in this study.

(Figure 4.1)

CODING STRATEGIES USED IN CAMPAIGN REWARDS

\begin{tabular}{|c|c|}
\hline Reward strategy & Code \\
\hline 1 -Purchase me & PURCH \\
\hline 2 - Top it up & TOPIT \\
\hline 3-Collectible tokens & COLLE \\
\hline 4 - Something special & SOMET \\
\hline 5 -Pursuit of pleasure & PURSU \\
\hline 6 - Highly appreciated & $\mathrm{HICH}$ \\
\hline 7 -Let's collaborate & LETS \\
\hline
\end{tabular}

Source: Elaborated by the authors.

After this step, we started to calibrate the data. The data calibration is performed to define the degrees in which cases belong or not to a given set (Dias, 2014). According to the QCA method, we tried to verify if the reward strategies belonged or not to the set of rewards with high contribution to the success of the campaign. The fuzzy set approach holds that an uncalibrated measure is smaller than a calibrated one (Garson, 2016; Ragin, 2008). In view of this, the calibration was carried out based on references to the scientific literature on the subject. According to Kuppuswamy and Bayus (2017), once the campaign reaches $50 \%$ of the stipulated target, at any time, the campaign has a $95 \%$ chance of reaching the total goal. On the other hand, campaigns that are below $40 \%$ or above $100 \%$ of the collection goal, close to the end date, suffer from the decrease in the support received (Kuppuswamy and Bayus, 2017). We started from these parameters established in the literature on the subject in our calibration. We have established four levels of 
contribution to the campaign. Rewards without contribution were those that contributed up to $20 \%$ of the campaign success; low contribution rewards were those that contributed between $20 \%$ and $40 \%$ of the campaign success; average contribution rewards were those that contributed between $40 \%$ and $80 \%$ of the campaign success, and; high contribution rewards were those that contributed over $80 \%$ of the campaign success.

After the calibration of the data, we used the fs software fs/QCA to perform the analysis in the so-called truth table. The truth table is the main tool for systematic analysis of causal relationships. From the calibrated data, the truth table constructs and identifies the connections (Ragin, 2008; Dias, 2015). Our main goal was to identify the explicit connections between the different combinations of causal conditions and outcomes. The table allows one to examine the distribution of cases through the possible logical combinations of a set of causal conditions, while, at the same time, ascertaining the degree to which cases with a particular combination agree with a particular outcome (Garson, 2016).

We performed the data analysis in two stages. In the first step, we analyzed all the rewards collected as a single group. In the second stage, we looked at the rewards according to their thematic category. The fs/QCA software allows a three-level solution analysis: Complex solution, parsimonious solution, and intermediate solution. In this study, we chose to consider the complex and the parsimonious solutions. The complex solution only analyzes rows that presented cases in the truth table. The remaining rows of the truth table are excluded. The parsimonious solution analyzes the remnant combinations of the truth table as a simplifying assumption and presents similar results as a conventional statistical analysis (Ragin, 2008).

We compared the terms of the complex and parsimonious solutions to highlight the causal conditions in the complex solution that do not contribute to the identification of the outcome condition (Garson, 2016). Through this analysis, we were able to cross the different findings to verify the similarities and differences of reward impacts in the results of the campaigns in the four thematic categories. We adopted two strategies in relation to validity. First, we increased the number of rewards scrutinized in order to reduce the impact of outliers. However, a large $\mathrm{N}$ by itself does not guarantee generalizability. So, we also applied matching techniques to improve the representativeness of the sample. The QCA method offer statistical measures of uncertainty for necessity and sufficiency claims for representative samples. (Thomann \& Maggetti, 2017). 


\section{RESULTS}

In order to promote a better understanding of the study, the first section presents the results of the strategies at the rewards level, adding the exploration of the rewards by category and discussing the key strategies and their impact on the success of CF campaigns.

\subsection{Rewards as a strategy}

The corpus of the empirical research data comprises 2,614 rewards, of which 1,468 were for the successful campaigns and 1,148 were for the unsuccessful campaigns. The rewards of the successful campaigns averaged 21 grants, with a median of five grants per reward. In the rewards for the non-successful campaigns, the average was two grants per reward. Among all the rewards of the successful campaigns, only 217 received no support. However, in unsuccessful campaigns, the number increases to 640 rewards without any support. In all, 857 rewards had no support, that is, $32.78 \%$ of the rewards did not influence the collection of resources in the campaigns. The results are summarized in Figure 5.1.1.

\section{(Figure 5.1.1)}

REWARDS CHARACTERIZATION

\begin{tabular}{lcc}
\hline & $\begin{array}{c}\text { Successful campaigns } \\
\text { rewards }\end{array}$ & $\begin{array}{c}\text { Unsuccessful campaigns } \\
\text { rewards }\end{array}$ \\
\hline Total rewards & 1,468 & 1,148 \\
\hline Average support & 21 & 2 \\
\hline Median support & 5 & 1 \\
\hline Rewards without support & 217 & 640 \\
\hline
\end{tabular}

Source: Elaborated by the authors.

The study of rewards began with the analysis of the truth table solutions. In the fuzzy set analysis, the cases were classified within the rows of the truth table, according to the degree of adhesion in each of the combinations. As a result of this classification, the truth table presented $25 \mathrm{com}$ binations with empirical cases. Within these combinations, the result that stood out from the others in the distribution of the cases in the truth table 
was the combination with the absence of all the strategies, since 2,427 rewards were classified in this row of the truth table. In other words, the strategies presented in these rewards contributed with percentages inferior to $20 \%$ of the total collected. Of these, 857 are rewards with no support, i.e., scored zero in all strategies. The others were classified in the rewards group with up to $20 \%$ contribution, that is, rewards with low contribution to the success of the campaign.

The complex solution of the fuzzy set analysis pointed to four possible paths of reward strategies with a high contribution to the success of the campaign in view of the consistency and the coverage of the results. The consistency of a result is "the degree to which the cases sharing a given combination of conditions agree in displaying the outcome in question" (Ragin, 2008, p. 44). All the four paths showed high consistency, or perfect consistency (raw consist $=1$ ). Coverage, on the other hand, means how closely the combination is relevant or necessary to the solution. The data collected resulted in low solution coverage, i.e., no reward strategy was identified as sufficient or even necessary for the campaign success.

Since the complex analysis only verifies the combinations that had evidence in the cases, we chose to compare these results to those of the parsimonious solution. This pointed two paths to a reward with a contribution to the success of the campaign, presented in the equation of Figure 5.1.2. The equation, read as [the presence of something special] or [the presence of purchase me, combined with the presence of top it up and Pursuit of pleasure], is consistent for the result, that is, the rewards with a contribution to the success of the campaign.

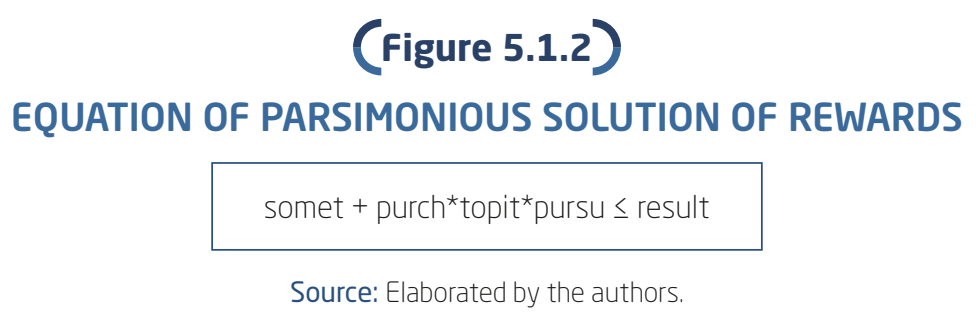

The parsimonious solution presents the equations of possible combinations of reward strategies that contribute to the success of the campaign. In other words, using the purchase me combined with top it up and pursuit of pleasure increases the likelihood that rewards will contribute to the success of the campaign. This result presented the perfect consistency $=1$, and the cases that were framed in this line of truth table also share this combination of rewards. Although the condition presented was consistent, it was not 
enough to impact the result, because the combination of purchase me, top it up and pursuit of pleasure rewards presented coverage for only one case.

The reward something special had a consistency of 0.988 , which shows that there are variations in the cases that share such a strategy. Although results demonstrate a consistency for the analysis, this strategy alone was not enough to impact the success of the campaigns. Both results were consistent for a reward with an average contribution to the success of the campaign. However, they are not enough or necessary for the rewards with a high contribution to the campaign. Results also show that the rewards let's collaborate, highly appreciated and collectible tokens are insufficient strategies, in terms of high contribution, to campaign success. In order to deepen these results, we analyze the rewards by thematic categories.

\subsection{Rewards by thematic category}

The purpose of the campaign and the thematic category provide an initial direction and a strategic filter for the entrepreneur (Thürridl \& Kamleitner, 2016). The photography category had the highest number of rewards analyzed (975), in contrast to the AUB, which presented the lowest number of rewards (304). Each of the categories was analyzed individually. Thus, the truth table of the FAD category presented 16 solutions with cases, followed by Science and Technology (SCT), with 13, PHO, with ten rows of the truth table, and AUB, with seven, as presented in Figure 5.2.1. Each category also presented the combined row, with the absence of all strategies. The AUB category presented 291 cases with the absence of the strategy row, followed by the SCT, with 589 rewards, PHO, with 942 rewards, and FAD, with 683 rewards.

(Figure 5.2.1)

CHARACTERIZATION OF REWARDS BY CATEGORY

\begin{tabular}{lcccc}
\hline & $\begin{array}{c}\text { Architecture } \\
\text { and urbanism }\end{array}$ & $\begin{array}{c}\text { Science and } \\
\text { technology }\end{array}$ & Photography & $\begin{array}{c}\text { Fashion and } \\
\text { design }\end{array}$ \\
\hline Total analyzed rewards & 304 & 609 & 975 & 726 \\
\hline Average support & 21.2 & 13.8 & 16.8 & 8.9 \\
\hline Median support & 3.0 & 2.0 & 3.0 & 1.0 \\
\hline Rewards with no support & 100 & 185 & 288 & 282 \\
\hline Rows of the truth table that & 7 & 13 & 10 & 16 \\
presented cases & 291 & 589 & 942 & 683 \\
\hline Cases with absence of strategy & & & & \\
\hline
\end{tabular}


We started the analysis with the complex solution of the rewards in each of the categories. The AUB, SCT and PHO categories presented only one reward solution to the campaigns, unlike the FAD category, which presented three different combinations of reward strategies. In this analysis, the reward Let's Collaborate presented the absence of strategy in all combinations. As the complex solution considers only the combinations that had evidence in the cases, we chose to study the data of the complex solution together with the parsimonious solution. The parsimonious solution, in turn, considers all combinations for the analysis, including the remnants, simplifying the result of the complex solution, represented by the equations of Figure 5.2.2.

\title{
(Figure 5.2.2)
}

\section{PARSIMONIOUS SOLUTIONS EQUATIONS BY CATEGORY}

\author{
Architecture and urbanism category - $\quad$ purch ${ }^{\star} \sim$ colle $\leq$ result \\ Science and technology category - $\quad$ purch*topit* pursu $\leq$ result \\ Photography category - \\ somet $\leq$ result \\ Fashion and design category - \\ somet $\leq$ result + colle $e^{\star}$ pursu $\leq$ result
}

Source: Elaborated by the authors.

In the AUB category, the QCA solution showed the presence of the purchase me and the absence of collectible tokens as a reward strategy. In the SCT category, the combination of the purchase me with top it up and pursuit of pleasure was indicated as a reward strategy. The PHO and FAD categories presented the reward something special as a strategy, and the FAD category presented an alternative path of reward strategies, combining collectible tokens with pursuit of pleasure.

\section{DISCUSSION}

The results enable us to advance in the discussion on the effect of reward strategies on the success of CF campaigns. Similar to other studies on collective action in crowds (Bénabou \& Tirole, 2006), the literature on CF yielded mixed results with respect to the effect of reward strategies. Rewards may be the key factor to the success, as well as they may not have any influence, and even become detrimental to CF campaigns. Because of that, some scholars question the relevance of rewards on CF campaigns (Kraus et al., 2016). 
Taking a step forward in understanding the effect of rewards on collective action, our study showed that tangible reward strategies stand out from symbolic ones. For instance, our results highlighted the reward something special as the main strategy that contributes to the success of a campaign. In addition, the results of the parsimonious solution showed the combination of purchase me with top it up and pursuit of pleasure as an effective strategy for CF campaigns in the four categories of analysis. In summary, we found that concrete benefits are more relevant to the success of CF campaigns than intangible rewards. Tangible rewards help prospective backers to assess the potential impact of their own contribution and overcome the threshold problem of collective action (Granovetter, 1978; Passy \& Giugni, 2001). We also analyzed the results by each of the four categories.

In the AUB category, our results pointed to the consistency of a combination of the presence of purchase me and the absence of the collectible tokens. This finding confirms the positive relationship found by Thürridl and Kamleitner (2016) between the purchase me strategy and the success of a campaign. In contrast, the collectible tokens undermine the success of the campaign. This result can be explained by the fact that collectible tokens require an earlier or later trajectory of similar rewards. Results also showed that rewards that offered tangible products in the AUB and SCT categories and used the purchase me strategy combined with other strategies raised more funds. Those findings reinforce the study by Hörisch (2015), whose evidence points out that campaigns with tangible objectives are more likely to be successful.

The reward something special is a solution that positively influences all combinations in which it is present. This reward was found in all strategies and was especially robust in the thematic categories since it was the only relevant reward in the PHO category and the main reward in FAD. The reward something special contributed particularly to the FAD category. In this category, all cases that had the presence of something special were successful. This evidence helps to reinforce the results of Thürridl and Kamleitner (2016), who found a positive relationship between something special and the success of a campaign. Our finding also corroborates earlier propositions that unique products or services are among the main wishes of the CF campaign backers (Ho et al., 2014). In other words, the main motivation of a backer is obtaining rewards, followed by helping others, supporting a cause, and belonging to a community (Gerber \& Hui, 2013). At the same time, our results also pointed out that collectible tokens combined with the pursuit of pleasure contributed to the success of FAD campaigns, reinforcing Thürridl 
and Kamleitner's (2016) theoretical proposition that collectible tokens require the support of another reward strategy.

Notwithstanding, other explanations cannot be disregarded in this analysis, such as the number of backers (Afuah \& Tucci, 2012), information on texts, images and videos (Koch \& Siering, 2015), constancy in campaign updating (Kuppuswamy \& Bayus, 2017), the engagement of the entrepreneur in social networks (Verschoore \& Zuquetto, 2016; Turi et al., 2017) and the recognition and attention of backers (Boudreau \& Jeppesen, 2015). Thus, our study reinforces the position of scholars who indicate a combination of factors in the success of campaigns, such as the number of updates made, the magnitude of goals and the number of feedbacks (Müllerleile and Joenssen, 2015; Kraus et al., 2016). Our results have practical implications as well. Entrepreneurs who strived for success in CF cannot limit their strategies to the rewards of their campaigns. Before proposing a goal for the $\mathrm{CF}$ campaign, entrepreneurs should assess their ability to communicate and relate to their networks of potential backers. Reward strategies are not the starting point of the campaign strategy, but a component that adds to the set of strategic decisions made before and during CF campaigns.

\section{CONCLUDING REMARKS}

This article addressed the topic of reward-based CF. Based on a qualitative empirical study, through a fuzzy set QCA method, we compared the effect of seven reward strategies on the success of the CF campaigns. We analyzed five categories of the catarse.me platform. Results showed that tangible strategies have a positive effect on CF campaigns. Among the reward strategies that contribute to the success of the campaign, something special and purchase me stood out. In addition, our results showed that something special is a relevant strategy and revealed that intangible rewards have no effect on CF campaigns. Even when analyzed in the four categories selected or combined in different sets of rewards, the effects of collectible tokens, pursuit of pleasure, and top it up on CF campaigns are not significant.

Academically, our study addressed the effect of reward strategies on collective action. The main theoretical contribution was to show the positive effect of tangible rewards on the success of CF campaigns. Our study also raised questions about the effect of intangible rewards on CF campaigns. Such a distinction is important, in view of the high percentage of the CF campaigns that do not reach the requested goal. For entrepreneurs, our 
results work as a guide for decision-making and reveal opportunities for combinations of reward strategies according to the campaign category. In addition, our findings allow entrepreneurs to plan their strategies to be used in the campaign as a whole, without the need to spend their main energy and investments directly on the rewards. For platforms, such as catarse.me, our study throws light on a reflection on the success factors in order to guide future actions and to develop better solutions for backers' engagement.

We understand that our results cannot be generalized to CF platforms around the world, not even in other contexts, such as loans, grants or seed capital. Our results also have limitations of methodological choices, such as the four selected categories. Throughout this study, we observed the behavior of CF rewards and the impact of strategies for campaign success. We thus recommend the establishment of relationships between the reward strategies and other factors related to the success of the CF campaigns already identified in the academic literature on CF, such as the impact of social networks, campaign updates, among others. Our study raises questions:

- Are low-target campaigns more likely to succeed?

- How does the entrepreneur set the goal of a campaign?

- How does the entrepreneur choose reward strategies?

- Are reward strategies different across platforms?

Future studies may also seek to relate the role of the CF platforms to the campaign development. We hope that studies will continue to expand the scope of the CF phenomenon, increase the chances of success of the initiatives and add knowledge to the movement of a sharing economy based on the collective action of crowds.

\section{O EFEITO DAS ESTRATÉGIAS DE RECOMPENSAS NO SUCESSO DAS CAMPANHAS DE FINANCIAMENTO COLETIVO}

\section{SESUMO}

Objetivo: O objetivo deste artigo é analisar o efeito de estratégias de recompensa no sucesso de campanhas de financiamento coletivo.

Originalidade/valor: O estudo contribui para o conhecimento das estratégias de recompensa do financiamento coletivo. Por meio de uma abor- 
dagem de análise comparativa, o estudo demonstrou diferenças no efeito das recompensas tangíveis, simbólicas e coletivas sobre o sucesso das campanhas de financiamento coletivo.

Design/metodologia/abordagem: O estudo emprega a abordagem da Análise Comparativa Qualitativa (ACQ) para analisar as campanhas de financiamento coletivo da catarse.me, uma plataforma brasileira.

Resultados: Recompensas tangíveis, como colecionáveis e pré-compra, têm um efeito positivo nas campanhas de crowdfunding de sucesso. Recompensas simbólicas e coletivas, como colecionáveis, experiência e agregação, não podem substituir os incentivos materiais das recompensas tangíveis. As principais descobertas mostram as oportunidades para combinações de estratégias de recompensa para o financiamento coletivo. Com base no estudo, os empreendedores podem planejar uma estratégia de recompensa para campanhas de financiamento coletivo. Os resultados são aplicáveis ao financiamento coletivo baseado em recompensas e não podem ser generalizados para outras plataformas em todo o mundo.

\section{PALAVRAS-CHAVE}

Financiamento coletivo. Empreendedorismo. Novos negócios. Fatores de sucesso. Recompensas.

\section{REFERENCES}

Afuah, A., \& Tucci, C. L. (2012). Crowdsourcing as a solution to distant search. Academy of Management Review, 37(3), 355-375. doi:10.5465/amr. 2010.0146

Agrawal, A., Catalini, C., \& Goldfarb, A. (2011). The geography of crowdfunding [Working Paper $\mathrm{n}^{\circ} \mathrm{w} 16820$ ]. National Bureau of Economic Research, Cambridge, MA.

Agrawal, A., Catalini, C., \& Goldfarb, A. (2015). Crowdfunding: geography, social networks, and the timing of investment decisions. Journal of Economics \& Management Strategy, 24(2), 253-274. doi:10.1111/jems.12093 
Balestrin, A., \& Verschoore, J. R. (2014). Réplica - redes são redes ou redes são organizações? Revista de Administração Contemporânea, 18(4), 523-533. doi:10.1590/1982-7849rac201410961

Belleflamme, P., \& Lambert, T. (2014). Crowdfunding some empirical findings and microeconomic underpinnings. Revue Bancaire et Financière, 4, 288-296. doi:10.2139/ssrn.2437786

Belleflamme, P. Lambert, T., \& Schwienbacher, A. (2014). Crowdfunding: Tapping the right crowd. Journal of Business Venturing, 29(5), 585-609. doi:10.1016/j.jbusvent.2013.07.003

Bénabou, R., \& Tirole, J. (2003). Intrinsic and extrinsic motivation. The Review of Economic Studies, 70(3), 489-520. doi:10.1111/1467-937X.00253

Bénabou, R., \& Tirole, J. (2006). Incentives and prosocial behavior. American Economic Review, 96(5), 1652-1678. doi:10.1257/aer.96.5.1652

Bernoff, J., \& Li, C. (2008). Harnessing the power of the oh-so-social web. MIT Sloan Management Review, 49(3), 36-42.

Boeuf, B., Darveau, J., \& Legoux, R. (2014). Financing creativity: Crowdfunding as a new approach for theatre projects. International Journal of Arts Management, 16(3), 33-48.

Boudreau, K. J, \& Jeppesen, L. B. (2015). Unpaid crowd complementors: The platform network effect mirage. Strategic Management Journal, 36(12), 1761-1777. doi:10.1002/smj.2324

Brabham, D. C. (2008). Crowdsourcing as a model for problem solving: An introduction and cases. Convergence, 14(1), 75-90. doi:10.1177/13548565 07084420

Burtch, G., Ghose, A., \& Wattal, S. (2015). The hidden cost of accommodating crowdfunder privacy preferences: A randomized field experiment. Management Science, 61(5), 949-962. doi:10.1287/mnsc.2014.2069

Canetti, E. (1984). Crowds and power. New York, NY: Farrar, Straus and Giroux.

Catarse (2017). R\$ 60 milhões apoiados a criadores independentes no Catarse. Retrieved from http://blog.catarse.me/60-milhoes-apoiadoscatarse-recorde-financiamento-coletivo/

Chen, S., Thomas, S., \& Kohli, C. (2016). What really makes a promotional campaign succeed on a crowdfunding platform? Journal of Advertising Research, 56(1), 81-94. doi:10.2501/JAR-2016-002

Colombo, M. G., Franzoni, C., \& Rossi-Lamastra, C. (2015). Internal social capital and the attraction of early contributions in crowdfunding. Entrepreneurship Theory and Practice, 39(1), 75-100. doi:10.1111/etap.12118 
Crosetto, P., \& Regner, T. (2018). It's never too late: Funding dynamics and self pledges in reward-based crowdfunding. Research Policy, 47(8), 14631477. doi:10.1016/j.respol.2018.04.020

Davidson, R., \& Poor, N. (2015). The barriers facing artists' use of crowdfunding platforms: Personality, emotional labor, and going to the well one too many times. New Media \& Society, 17(2), 289-307. doi:10.1177/146 1444814558916

Dias, C. N. (2015). A influência das redes interorganizacionais e da complementaridade de recursos no desempenho da inovação: Um estudo comparativo Brasil-Espanha no setor de pesquisa agropecuária (Tese de doutorado, Universidade de Brasília).

Dias, O. C. (2014). Parcerias público-privadas como instrumento de implementação de políticas públicas (Tese de doutorado, Universidade de Brasília).

Easley, D., \& Kleinberg, J. (2010). Networks, crowds, and markets: Reasoning about a Highly Connected World. New York, NY: Cambridge University Press.

Frey, B. S., \& Jegen, R. (2001). Motivation crowding theory. Journal of Economic Surveys, 15(5), 589-611. doi:10.1111/1467-6419.00150

Frydrych, D., Bock, A. J., Kinder, T., \& Koeck, B. (2014). Exploring entrepreneurial legitimacy in reward-based crowdfunding. Venture Capital, 16(3), 247-269. doi: 10.1080/13691066.2014.916512

Garson, G. D. (2016). Case study analysis \& QCA. Asheboro, NC: Statistical Associates Publishers.

Gerber, E. M., \& Hui, J. S. (2013). Crowdfunding: motivations and deterrents for participation. ACM Transactions on Computer-Human Interaction, 20(6), 1-32. doi:10.1145/2530540

Gerber, E. M., Hui, J. S., \& Kuo, P. Y. (2012) Crowdfunding: Why people are motivated to post and fund projects on crowdfunding platforms. Proceedings of the International Workshop on Design, Influence, and Social Technologies: Techniques, Impacts and Ethics, USA, 11, 10.

Gleasure, R. (2015). Resistance to crowdfunding among entrepreneurs: An impression management perspective. Journal of Strategic Information Systems, 24(4), 219-233. doi:10.1016/j.jsis.2015.09.001

Granovetter, M. (1978). Threshold models of collective behavior. American Journal of Sociology, 83(6), 1420-1443. doi:10.1086/226707

Ho, H. Y., Lin, P. C., \& Lu, M. H. (2014). Effects of online crowdfunding on consumers' perceived value and purchase intention. Anthropologist, 17(3), 837-844. doi:10.1080/09720073.2014.11891498 
Hobbs, J., Grigore, G., \& Molesworth, M. (2016). Success in the management of crowdfunding projects in the creative industries. Internet Research, 26(1), 146-166. doi:10.1108/IntR-08-2014-0202

Hörisch, J. (2015). Crowdfunding for environmental ventures: An empirical analysis of the influence of environmental orientation on the success of crowdfunding initiatives. Journal of Cleaner Production, 107, 636-645. doi:10.1016/j.jclepro.2015.05.046

Kaartemo, V. (2017). The elements of a successful crowdfunding campaign: A systematic literature review of crowdfunding performance. International Review of Entrepreneurship, 15(3), 291-318.

Koch, J. A., \& Siering, M. (2015). Crowdfunding success factors: The characteristics of successfully funded projects on crowdfunding platforms. European Conference on Information Systems (ECIS), Münster, Germany, 23.

Kraus, S, Richter, C., Brem, A., Cheng, C. F., \& Chang, M. L. (2016). Strategies for reward-based crowdfunding campaigns. Journal of Innovation $\mathcal{E}$ Knowledge, 1(1), 13-23. doi:10.1016/j.jik.2016.01.010

Kuppuswamy, V., \& Bayus, B. L. (2017). Does my contribution to your crowdfunding project matter? Journal of Business Venturing, 32(1), 72-89. doi:10.1016/j.jbusvent.2016.10.004

Kuppuswamy, V., \& Bayus, B. L. (2018). Crowdfunding creative ideas: The dynamics of project backers in Kickstarter. In D. Cumming \& L. Hornuf (Eds.). The economics of crowdfunding (pp. 151-182). Cham: Palgrave Macmillan.

Lehner, O. M. (2013). Crowdfunding social ventures: A model and research agenda. Venture Capital, 15(4), 289-311. doi:10.1080/13691066.2013.782624

McKenny, A. F., Allison, T. H., Ketchen Jr., D. J., Short, J. C., \& Ireland, R. D. (2017). How should crowdfunding research evolve? A survey of the entrepreneurship theory and practice editorial board. Entrepreneurship Theory and Practice, 41 (2), 291-304. doi:10.1111/etap.12269

Michelucci, P., \& Dickinson, J. L. (2016). The power of crowds. Science, 351 (6268), 32-33. doi:10.1126/science.aad6499

Mollick, E. (2014). The dynamics of crowdfunding: An exploratory study. Journal of Business Venturing, 29(1), 1-16. doi:10.1016/j.jbusvent.2013. 06.005

Momboisse, R. (1967). Riots, revolts and insurrections. Springfield, IL: Charles C. Thomas. 
Müllerleile, T., \& Joenssen, D. W. (2015). Key success-determinants of crowdfunded projects: An exploratory analysis. In B. Lausen, S. KrolakSchwerdt, \& M. Böhmer. Data science, learning by latent structures, and knowledge discovery (pp. 271-281). London: Springer.

Passy, F., \& Giugni, M. (2001). Social networks and individual perceptions: Explaining differential participation in social movements. Sociological Forum, 16(1), 123-153. doi:10.1023/A:1007613403970

Ragin, C. C. (1987). The comparative method: Moving beyond qualitative and quantitative strategies. Berkeley, CA: University of California Press.

Ragin, C. C. (2000). Fuzzy-set social science. Chicago, IL: University of Chicago Press.

Ragin, C. C. (2008). Redesigning social inquiry: Fuzzy sets and beyond. Chicago, IL: University of Chicago Press.

Rihoux, B. (2003). Bridging the gap between the qualitative and quantitative worlds? A retrospective and prospective view on qualitative comparativeanalysis.FieldMethods, 15(4),351-365.doi:10.1177/1525822X03257690

Schijven, M., \& Hitt, M. A. (2012). The vicarious wisdom of crowds: Toward a behavioral perspective on investor reactions to acquisition announcements. Strategic Management Journal, 33(11), 1247-1268. doi:10.1002/ smj.1984

Stieger, D., Matzler, K., Chatterjee, S., \& Ladstaetter-Fussenegger, F. (2012). Democratizing strategy: How crowdsourcing can be used for strategy dialogues. California Management Review, 54(4), 44-68. doi:10.1525/cmr.2012. 54.4.44

Thomann, E., \& Maggetti, M. (2017). Designing research with Qualitative Comparative Analysis (QCA): Approaches, challenges, and tools. Sociological Methods \& Research. doi:10.1177/0049124117729700

Thürridl, C., \& Kamleitner, B. (2016). What goes around comes around? Rewards as strategic assets in crowdfunding. California Management Review, 58(2), 88-110. doi:10.1525/cmr.2016.58.2.88

Turi, A. N., Domingo-Ferrer, J., Sánchez, D., \& Osmani, D. (2017). A co-utility approach to the mesh economy: The crowd-based business model. Review of Managerial Science, 11(2), 411-442. doi:10.1007/s11846-0160192-1

Valančienė, L., \& Jegelevičiūtè, S. (2014). Crowdfunding for creating value: Stakeholder approach. Procedia-Social and Behavioral Sciences, (156), 599-604. doi:10.1016/j.sbspro.2014.11.248 
Verschoore, J. R., \& Zuquetto, R. D. (2016). A social network approach for crowdfunding. In J. Méric, J. Brabet, \& I. Maque. International perspectives on crowdfunding: Positive, normative and critical theory (pp. 151-167). London: Emerald.

Zheng, H., Li, D., Wu, J., \& Xu, Y. (2014). The role of multidimensional social capital in crowdfunding: A comparative study in China and US. Information \& Management, 51 (4), 488-496. doi:10.1016/j.im.2014.03.003

\section{AUTHOR NOTES}

Jorge R. Verschoore, Ph.D. from the Postgraduate Program in Administration (PPGA), Federal University of Rio Grande do Sul (UFRGS); Mariana D. M. Araújo, master from the Postgraduate Program in Administration (PPGA), Vale do Rio dos Sinos University (Unisinos).

Jorge R. Verschoore is now professor at the Postgraduate Program in Administration (PPGA) of the Vale do Rio dos Sinos University (Unisinos); Mariana D. M. Araújo is now senior analyst and egress from the Vale do Rio dos Sinos University (Unisinos).

Correspondence concerning this article should be addressed to Jorge R. Verschoore, Avenida Nilo Peçanha, 1600, Boa Vista, Porto Alegre, Rio Grande do Sul, Brazil, CEP 90.470-280.

E-mail: jorgevf@unisinos.br

\section{EDITORIAL BOARD}

Editor-in-chief

Gilberto Perez

Associated Editor

Maurício Reinert do Nascimento

Technical Support

Vitória Batista Santos Silva

\section{EDITORIAL PRODUCTION}

Publishing Coordination

Jéssica Dametta

Layout Designer

Editorial Intern

Paula Di Sessa Vavlis

Language Editor

Daniel de Almeida Leão
Emap

Graphic Designer

Libro 